\title{
Antibiotic prescribing in UK care homes 2016-2017: retrospective cohort study of linked data
}

Catherine M. Smith ${ }^{1 *}$ D, Haydn Williams ${ }^{2}$, Arnoupe Jhass ${ }^{1,3}$, Selina Patel ${ }^{1}$, Elise Crayton ${ }^{4}$, Fabiana Lorencatto ${ }^{4}$, Susan Michie ${ }^{4}$, Andrew C. Hayward ${ }^{5}$, Laura J. Shallcross ${ }^{1}$ and on behalf of the Preserving Antibiotics through Safe Stewardship group

\begin{abstract}
Background: Older people living in care homes are particularly susceptible to infections and antibiotics are therefore used frequently for this population. However, there is limited information on antibiotic prescribing in this setting. This study aimed to investigate the frequency, patterns and risk factors for antibiotic prescribing in a large chain of UK care homes.

Methods: Retrospective cohort study of administrative data from a large chain of UK care homes (resident and care home-level) linked to individual-level pharmacy data. Residents aged 65 years or older between 1 January 2016 and 31 December 2017 were included. Antibiotics were classified by type and as new or repeated prescriptions. Rates of antibiotic prescribing were calculated and modelled using multilevel negative binomial regression.

Results: 13,487 residents of 135 homes were included. The median age was $85 ; 63 \%$ residents were female. 28,689 antibiotic prescriptions were dispensed, the majority were penicillins $(11,327,39 \%)$, sulfonamides and trimethoprim $(5818,20 \%)$, or other antibacterials $(4665,16 \%) .8433$ (30\%) were repeat prescriptions. The crude rate of antibiotic prescriptions was 2.68 per resident year (95\% confidence interval (Cl) 2.64-2.71). Increased antibiotic prescribing was associated with residents requiring more medical assistance (adjusted incidence rate ratio for nursing opposed to residential care $1.21,95 \% \mathrm{Cl} 1.13-1.30$ ). Prescribing rates varied widely by care home but there were no significant associations with the care home-level characteristics available in routine data.
\end{abstract}

Conclusions: Rates of antibiotic prescribing in care homes are high and there is substantial variation between homes. Further research is needed to understand the drivers of this variation to enable development of effective stewardship approaches that target the influences of prescribing.

Keywords: Anti-bacterial agents, Long-term care, Antibiotic stewardship, Antibiotic prescribing, care home, Older people, Infection

\footnotetext{
* Correspondence: catherine.m.smith@ucl.ac.uk

${ }^{1}$ Institute of Health Informatics, University College London, London NW1

2DA, UK

Full list of author information is available at the end of the article
}

(c) The Author(s). 2020 Open Access This article is licensed under a Creative Commons Attribution 4.0 International License, which permits use, sharing, adaptation, distribution and reproduction in any medium or format, as long as you give appropriate credit to the original author(s) and the source, provide a link to the Creative Commons licence, and indicate if changes were made. The images or other third party material in this article are included in the article's Creative Commons licence, unless indicated otherwise in a credit line to the material. If material is not included in the article's Creative Commons licence and your intended use is not permitted by statutory regulation or exceeds the permitted use, you will need to obtain permission directly from the copyright holder. To view a copy of this licence, visit http://creativecommons.org/licenses/by/4.0/ The Creative Commons Public Domain Dedication waiver (http://creativecommons.org/publicdomain/zero/1.0/) applies to the data made available in this article, unless otherwise stated in a credit line to the data. 


\section{Background}

Around one in seven people aged over 85 live in approximately 20,000 care homes in the United Kingdom [1-5]. This includes residential homes, which provide accommodation and personal care, and nursing homes, in which at least one qualified nurse is always on duty [6]. Care home residents are at increased risk of acquiring infections owing to age-related biological factors combined with environmental factors of the care home setting [7]. Chest infections, gastrointestinal infections, urinary tract infections, and skin and soft tissue infections are commonly reported and can cause outbreaks $[7,8]$.

As a result of the high frequency of symptoms that may indicate infection, antibiotics are used frequently for care home residents and there is potential for development of antibiotic resistance $[9,10]$. Frequent antibiotic use can be problematic for this population because they are at increased risk of adverse events related to antibiotic treatment such as infection with Clostridium difficile, side effects, and drug-drug interactions [9]. Residents admitted to hospital frequently return to care homes and then go back to hospital, creating the opportunity for transmission of infections, including drug-resistant pathogens, between healthcare settings [11]. Avoiding these adverse events requires identification of opportunities to safely reduce antibiotic use (antibiotic stewardship). To do this, detailed information on how antibiotics are currently used in this setting is needed.

Current evidence on antibiotic prescribing in care homes in the UK has largely been derived from pointprevalence surveys, including three European Centre for Disease Prevention and Control (ECDC)-coordinated projects (Healthcare-associated infections in long-term care facilities, HALT) in 2010, 2013 and 2016-17 [1214]. The most recent HALT survey involved care homes in 26 countries including 70 homes in Northern Ireland, 52 in Scotland and 28 in Wales (England did not participate). The point prevalence of antibiotic use was $4.9 \%$ across Europe and ranged from 5 to $10 \%$ in participating UK administrations [14]. A separate UK point prevalence survey, conducted in 644 long-term care facilities in 2017, found mean antibiotic prevalence of $7.7 \%$ in nursing homes and $6.7 \%$ in residential homes, and a mean of 1.04 antibiotics per resident [15]. Although these surveys provide overall estimates of antibiotic use, they are prone to seasonal variation and may not be representative.

A recent study described antibiotic prescriptions dispensed mainly to care home residents from a UK national pharmacy chain [16]. Although this study reported that half the residents included were prescribed at least one antibiotic per year, it did not include any resident data (such as age, date of entry to or exit from the care home, or date of death), precluding calculation of person-time denominators. The study was therefore unable to estimate rates of prescribing or assess factors associated with high prescribing. Analyses of primary care electronic health records have shown that prescribing increases in older age groups in the UK [17, 18]. However, these analyses provide little insight into patterns of prescribing to care home residents because care home residency is poorly recorded in UK electronic health records.

In this study, we used linked pharmacy and administrative data to investigate antibiotic prescribing to residents of a large chain of UK care homes. Our aims were to describe the types of antibiotics used for care home residents, estimate the rate of antibiotic prescribing, measure variation in prescribing by care home, and investigate care home and resident factors associated with prescribing.

\section{Methods}

There is no mandatory surveillance system for care homes in the UK and care home residency is not routinely recorded in electronic health records (primary or secondary care). We therefore used administrative systems from a large chain of care homes and did a retrospective cohort study including residents of these homes between 1 January 2016 and 31 December 2017. Here we describe the data available in these systems. Care home administrative systems were used to describe the characteristics of residents and care homes. Individuallevel prescriptions dispensed to residents of these homes were obtained by linkage to data from a national pharmacy chain.

\section{Care home administrative data}

We extracted data from routine care home administrative systems on resident and care home characteristics. Resident characteristics available were: age, sex, length of stay, residential or nursing care (i.e. at least one qualified nurse on duty at all times), whether the resident had dementia, and their status at the end of the study period (in the home, transferred out, or died). Care home-level characteristics available were: location, number of beds, number of clinical and care staff, and Care Quality Commission (CQC) rating (homes in England only)). We also extracted information on suspected incidents of infection (number and type) for each resident reported during the study period through an internal incident monitoring system used by the care home chain. This system is not linked to microbiological testing and therefore does not differentiate between suspected infections (identified by care home staff) and those confirmed microbiologically. We classified homes as urban or rural and according to deprivation decile using countryspecific indices [19-25]. 


\section{Dispensed prescriptions}

A large national pharmacy chain is contracted to fulfil drug prescriptions for residents of the care home chain. We extracted British National Formulary (BNF) drug classifications and date dispensed from the pharmacy database on all drugs dispensed to residents of the care homes during the study period. We linked individuallevel pseudonymised pharmacy and resident data using an identifier comprised of resident first initial, Soundex (a phonetic algorithm for indexing family names by sound), birth year, and care home identifier. Although the pharmacy chain is contracted to dispense all drugs to residents of the care home chain, we found that some care homes had few residents matching to prescriptions (suggesting that prescriptions were dispensed from elsewhere). We therefore excluded data from homes for which less than $75 \%$ of the residents had at least one prescription (of any drug or device). As a sensitivity analysis, we included only residents for which at least one prescription was matched (regardless of overall home proportion). In both analyses, we also excluded residents aged under 65 and individuals who entered and left the care home on the same day.

This study was approved by the UCL Research Ethics Committee (ID 11813/002).

\section{Description of residents, care homes and antibiotics}

We described resident and care home-level characteristics using counts and proportions. As a simple measure of co-morbidity, we calculated the number of chapters of the BNF (excluding antibiotics) from which residents had repeated drug prescriptions during the study period. We assumed that repeated prescriptions from more chapters would indicate a likely higher level of comorbidity (although this is not intended to represent an estimate of the number of conditions).

We identified antibiotics in the pharmacy data using BNF chapter 5 (infections) and subchapter 5.1 (antibacterials) [26, 27], and described antibiotic prescriptions by class using the Anatomical Therapeutic Chemical (ATC) system [28]. We classified antibiotics as new or repeated prescriptions using a cut-off of 35 days: If an antibiotic was prescribed within 35 days of a previous prescription of the same drug, it was classified as a repeat prescription. The 35 day cut-off was based on the distribution of time between prescriptions of the same antibiotic (Additional file 1). We calculated the total number of new and repeat prescriptions and the median number of repeats for each type of antibiotic.

\section{Estimation of antibiotic prescribing rates and factors associated with prescribing}

We described resident and care home-level characteristics using counts and proportions. We calculated the crude rate of antibiotic prescribing per resident year and the median rate for individual residents. We plotted rates by care home and calculated the intra-class correlation coefficient.

We used multilevel negative binomial regression to model antibiotic prescribing rates including random effects to account for clustering at the level of the care home. We assessed single variable associations with resident- and care home-level variables and included variables that showed some association with the outcome in a multivariable model (age and gender were also included in multivariable models). Rural-urban classification, deprivation decile and CQC rating are not standardised across UK administrations. We therefore ran separate single- and multivariable models for England, Northern Ireland, Scotland, and Wales including these variables in addition to those in the main regression analysis.

Analyses were conducted using R v3.5.1, using the lme4 package for mixed effects models [29].

\section{Results \\ Study population}

Between 1 January 2016 and 31 December 2017, there were 27,075 residents of the 258 care homes operated by the chain. In 135 care homes at least $75 \%$ of residents matched to at least one pharmacy record, with a total of 14,194 residents in these homes. A further 657 residents were excluded because they were aged under 65 years and 50 because they entered and left the home on the same day. The cohort therefore included 13,487 residents of 135 care homes, who stayed for a total of 3,916, 931 resident-days (10,731 resident-years) during the study period. Characteristics of residents and care homes included and excluded from the main analysis were similar (Additional file 2).

Resident and care home characteristics are shown in Table 1. Most care homes were in England (93/135, $69 \%)$, and located in urban areas $(84 / 93,90 \%$ care homes in England; 17/20, 85\% in Northern Ireland; 19/19, 100\% in Scotland, and 1/3,33\% in Wales). The median number of beds was 50 (range 25 to 111). The majority of residents were female $(8518 / 13,487,63 \%)$ and the median age was 85 (interquartile range (IQR) 79 to 90). Most residents had nursing care (9109/13,487, 68\%), $39 \%(4217 / 13,487)$ had dementia, and 7027 residents (52\%) died during the study period. The median number of BNF chapters from which residents had repeated prescriptions (excluding antibiotics) was 4 (IQR 1 to 5 ). The median resident length of stay during the study period was 210 days (IQR 51 to 509) and the median total resident length of stay (from date of admission to the home) was 333 days (IQR 67 to 913). 
Table 1 Resident and care home characteristics

\begin{tabular}{|c|c|c|}
\hline Variable & Number & Percent \\
\hline \multicolumn{3}{|l|}{ Resident-level $(n=13,487)$} \\
\hline \multicolumn{3}{|l|}{ Gender } \\
\hline Male & 8518 & 63.2 \\
\hline Female & 4969 & 36.8 \\
\hline \multicolumn{3}{|l|}{ Age } \\
\hline $65-74$ & 1871 & 13.9 \\
\hline $75-84$ & 5049 & 37.4 \\
\hline $85-94$ & 5691 & 42.2 \\
\hline $95+$ & 876 & 6.5 \\
\hline \multicolumn{3}{|l|}{ Type of care } \\
\hline Residential & 4354 & 32.3 \\
\hline Nursing & 9109 & 67.5 \\
\hline \multicolumn{3}{|l|}{ Dementia } \\
\hline No & 8246 & 61.1 \\
\hline Yes & 5217 & 38.7 \\
\hline \multicolumn{3}{|l|}{ Respite care } \\
\hline No & 11,459 & 85.0 \\
\hline Yes & 2028 & 15.0 \\
\hline $\begin{array}{l}\text { Length of stay during study period (days) Median } \\
\text { (IQR) }\end{array}$ & 210 & $51-509$ \\
\hline Overall length of stay (days) Median (IQR) & 333 & $67-913$ \\
\hline \multicolumn{3}{|l|}{ Entered care home during study period } \\
\hline No & 5587 & 41.4 \\
\hline Yes & 7900 & 58.6 \\
\hline \multicolumn{3}{|l|}{ Status at end of study period } \\
\hline In home & 3772 & 28.0 \\
\hline Permanently Discharged & 2688 & 19.9 \\
\hline Died & 7027 & 52.1 \\
\hline \multicolumn{3}{|l|}{ Number of reported infection episodes during study } \\
\hline 0 & 8993 & 66.7 \\
\hline 1 & 2217 & 16.4 \\
\hline More than 1 & 2277 & 16.9 \\
\hline
\end{tabular}

Number of BNF chapters with repeated prescriptions (excluding antibiotics)

$\begin{array}{lll}0-1 & 3907 & 29.0 \\ 2-4 & 4275 & 31.7 \\ 5-7 & 4693 & 34.8 \\ 8 \text { or more } & 612 & 4.5\end{array}$

Care home-level $(n=135)$

$\begin{array}{lll}\text { Country } & & \\ \text { England } & 93 & 68.9 \\ \text { Northern Ireland } & 20 & 14.8 \\ \text { Scotland } & 19 & 14.1 \\ \text { Wales } & 3 & 2.2\end{array}$

Number of beds
Table 1 Resident and care home characteristics (Continued)

\begin{tabular}{|c|c|c|}
\hline Variable & Number & Percentage \\
\hline$<40$ & 34 & 25.2 \\
\hline $40-49$ & 37 & 27.4 \\
\hline $50-59$ & 34 & 25.2 \\
\hline $60+$ & 30 & 22.2 \\
\hline \multicolumn{3}{|c|}{ Median overall length of stay } \\
\hline$<1$ year & 34 & 25.2 \\
\hline $1-2$ years & 85 & 63.0 \\
\hline$>2$ years & 16 & 12.9 \\
\hline \multicolumn{3}{|c|}{ Clinical staff per 100 residents } \\
\hline$<10$ & 35 & 25.9 \\
\hline $10-19$ & 65 & 48.2 \\
\hline $20+$ & 35 & 25.9 \\
\hline \multicolumn{3}{|c|}{ Care staff per 100 residents } \\
\hline$<60$ & 33 & 24.4 \\
\hline $60-79$ & 75 & 55.6 \\
\hline $80+$ & 27 & 20.0 \\
\hline \multicolumn{3}{|c|}{ Percentage residents with dementia } \\
\hline$<10$ & 35 & 25.9 \\
\hline $10-80$ & 80 & 59.3 \\
\hline 80-100 & 20 & 14.8 \\
\hline \multicolumn{3}{|c|}{ Percentage residents with nursing care } \\
\hline$<10$ & 20 & 14.8 \\
\hline $10-80$ & 58 & 43.0 \\
\hline $80-100$ & 57 & 42.2 \\
\hline \multicolumn{3}{|c|}{ Number of infection incidents per bed per year } \\
\hline Less than 1 & 70 & 51.9 \\
\hline 1 to 2 & 39 & 28.9 \\
\hline 2 or more & 26 & 19.3 \\
\hline
\end{tabular}

\section{Antibiotics}

A total of 28,689 antibiotic prescriptions were dispensed, and the most common ATC classes of antibiotics used were penicillins $(11,327 / 28,689,39 \%$ prescriptions), sulfonamides and trimethoprim $(5818 / 28,689,20 \%)$, and other antibacterials $(4665 / 28,689,16 \%)$. We classified $70 \%(20,223 / 28,689)$ antibiotics as new prescriptions and $30 \%(8466 / 28,689)$ as repeats. The prescription was a one-off for $89 \%(18,002 / 20,223)$ new prescriptions, the remaining $11 \%(2221 / 20,223)$ were new prescriptions that led to repeats. When the antibiotic was repeated at least once, the median number of antibiotic prescriptions was 2 (IQR 2-3, maximum 26), and the median number of days between the first and last prescription was 21 (IQR 8-35). The antibiotics that were repeated over the longest time were azithromycin, cephalexin, nitrofurantoin and trimethoprim (Fig. 1). The median 


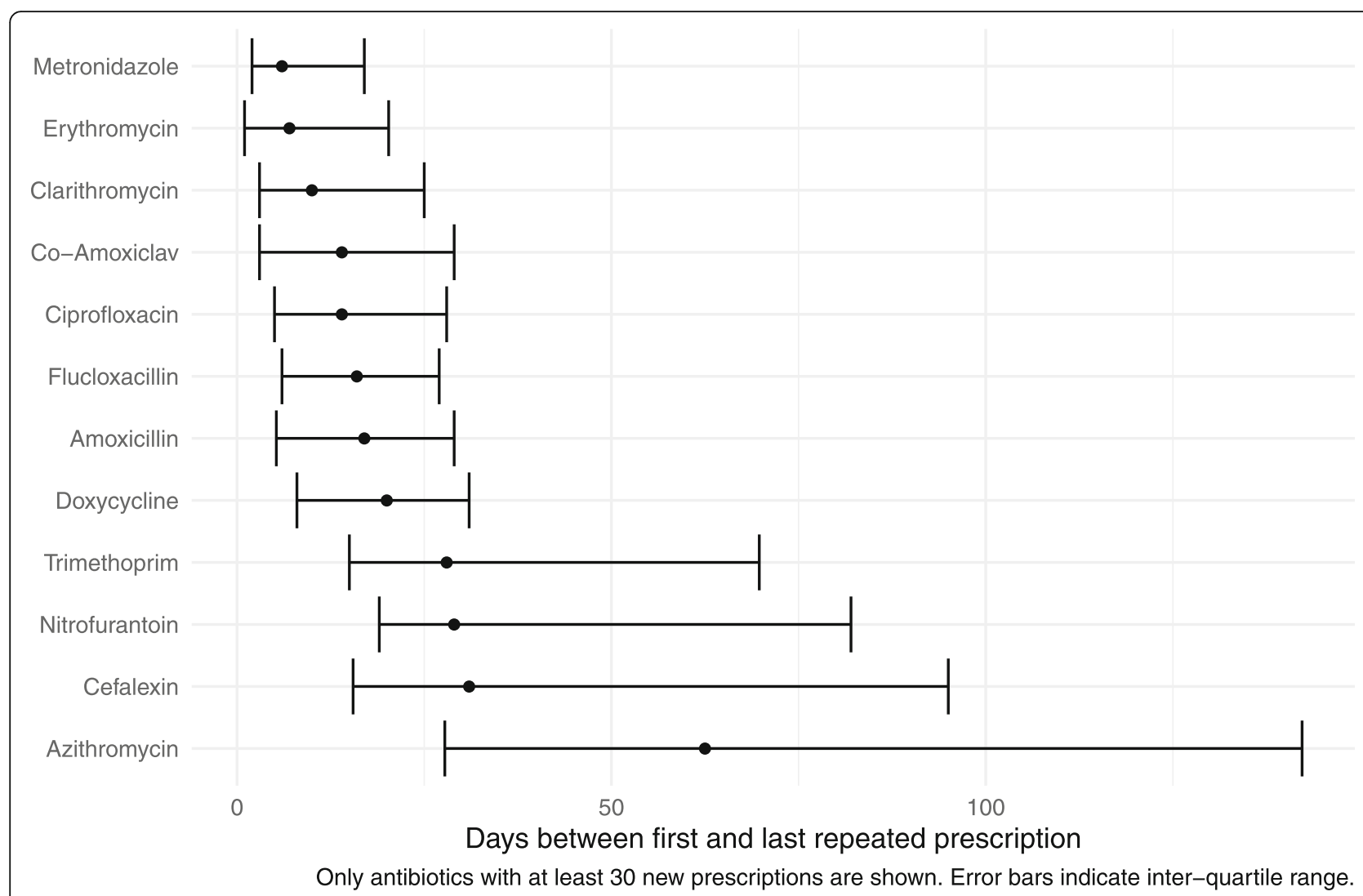

Fig. 1 Length of repeated antibiotic prescriptions

number of days between the first and last prescriptions of azithromycin was 62 (IQR 28-142).

\section{Antibiotic prescribing rates and factors associated with prescribing}

The crude rate of prescribing was 2.68 prescriptions per resident year (95\% confidence interval (CI) 2.64-2.71). The median rate of antibiotic prescriptions for an individual resident per year was 0.71 (IQR 0-3.70). Rates varied by home (median 2.67 IQR 2.07-3.29 antibiotic prescriptions per resident year, Fig. 2), but prescribing rates within homes were not highly correlated (intraclass correlation coefficient 0.19 ).

Rates of prescribing according to resident and care home characteristics and unadjusted results of negative binomial regression analyses are shown in Table 2 (country specific-models in Additional File 3). The final model (Table 3) was adjusted for resident age, sex, and variables that were associated with antibiotic prescribing at single variable analysis: residential or nursing care, dementia, respite care, care home entry during study period, status at end of study period (still in home, died, transferred out), number of infections reported, number of BNF chapters with repeat prescriptions. In the adjusted model, increased antibiotic prescribing was associated with care home entry during the study period (adjusted incidence rate ratio, aIRR 1.37, 95\% CI 1.30-1.44); having nursing care (aIRR 1.21, 95\% CI 1.13-1.30); death during the study period (aIRR 1.58, 95\% CI 1.50-1.67), and those who were permanently discharged from the home (aIRR 1.44, 95\% CI 1.32-1.57). Increased numbers of reported infections (aIRR for two or more infections compared to none 2.09 , 95\% CI 1.96-2.24) and higher levels of co-morbidity (aIRR for 5-7 BNF chapters with repeat prescriptions compared to 1 chapter 2.38, 95\% CI 2.16-2.62; for 8 or more chapters 2.89, 95\% CI 2.54-3.28) were also associated with increased antibiotic prescribing. There were no clear associations between antibiotic prescribing and resident age, sex, or care home-level variables.

\section{Sensitivity analysis}

In the sensitivity analysis based on residents who had at least one pharmacy record, 16,247 residents were included across 235 homes. The total follow-up time was $5,178,046$ resident-days (14,186 resident-years). There were 39,809 antibiotic prescriptions, a crude rate of 2.81 antibiotic prescriptions per resident year $(95 \%$ CI $2.78-$ 2.84). Negative binomial regression models resulted in 


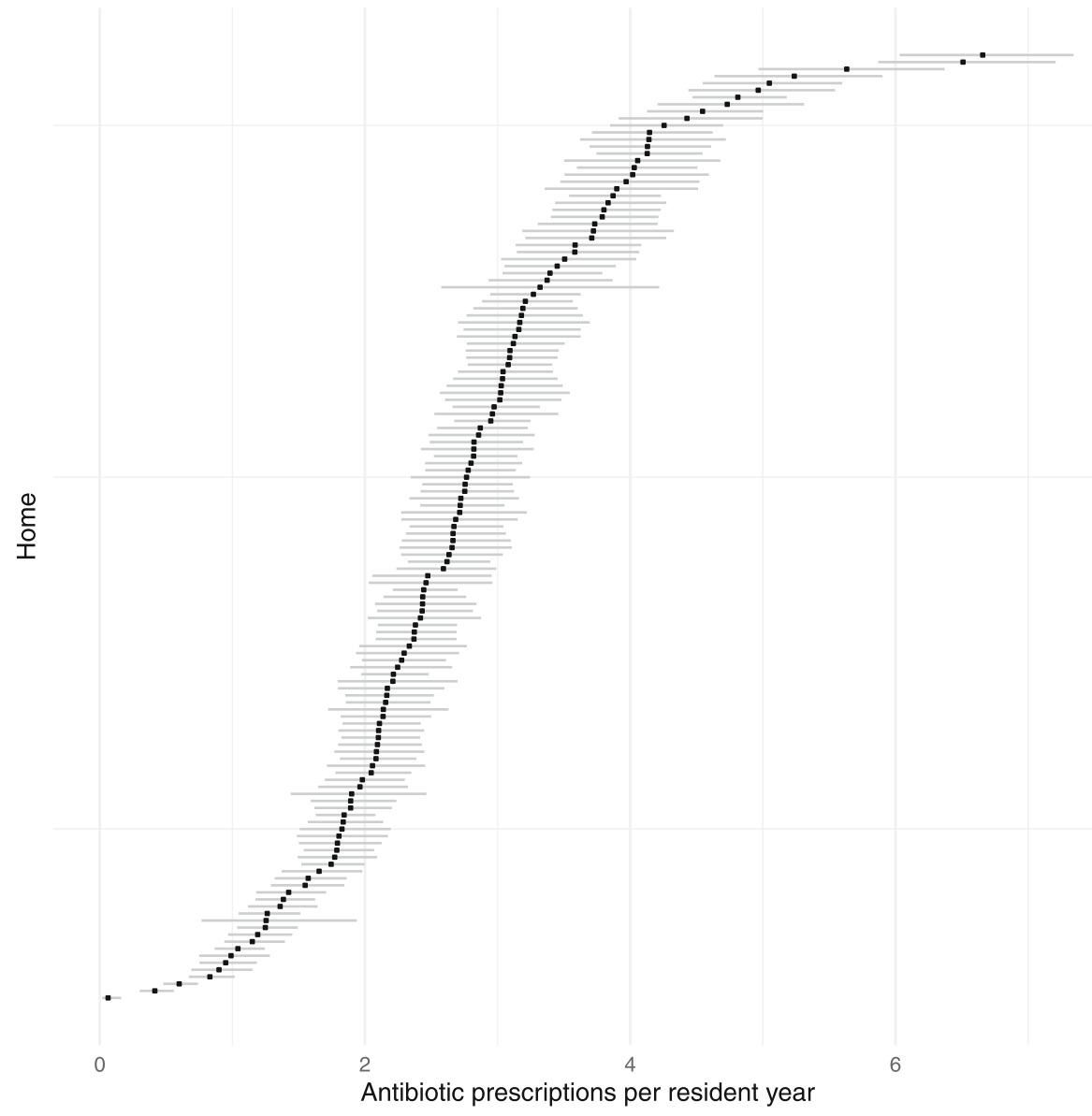

Fig. 2 Crude rates and 95\% confidence intervals of antibiotic prescribing by care home

similar associations to the main analysis. Full results of sensitivity analyses are shown in Additional File 4.

\section{Discussion}

In this study of linked administrative and pharmacy data, we have demonstrated high rates of antibiotic prescribing for care home residents with large variation by home. There were clear associations between higher prescribing and resident factors, but we found no significant associations between prescribing rates and care homelevel characteristics. We estimated that $30 \%$ of all antibiotic prescriptions dispensed were repeat prescriptions.

This was the first large-scale study in the UK to estimate rates of antibiotic use for care home residents. Our estimate of 2.68 antibiotic prescriptions per resident year is comparable to to estimates from smaller studies of care home residents in Hampshire, England (1.99 per resident year) [10] and South Wales (2.16 per resident year) [30]. These estimates are higher than rates for older adults in the general population in England derived from primary care data, which have been estimated at 1.06 per year for those aged 65-84, [17] 1.50 per year for those aged 85 and over, [17] and 1.13 per year for all those aged over 65 [18]. There are few published comparable European or other international estimates from care home settings. A USA study in 2001-2002 reported a rate of 1.75 prescriptions per resident year [31]; a study in British Columbia, Canada in 2007-2014 reported 3539 defined daily doses of antibiotics per 1000 resident days [32], and a study in Ontario, Canada reported 55 antibiotic days per 1000 resident days [33]. As our study measured rates of prescribing, and we lacked reliable information on the duration of therapy for each dispensed antibiotic, our estimates are not directly comparable to the HALT point prevalence surveys [12-14].

We found that higher rates of antibiotic prescribing were associated with residents who were likely to be more unwell, including those who had more infections, more probable co-morbidities (defined by repeated prescriptions from more BNF chapters), and those who died or permanently moved out of the home (likely to hospital) during the study period. There was also an association between higher antibiotic prescribing and residents who had recently moved into a home. Assuming that 
Table 2 Rates and single variable analysis of antibiotic prescribing by resident and care home characteristics

\begin{tabular}{|c|c|c|c|c|}
\hline Variable & $\begin{array}{l}\text { Number of antibiotic } \\
\text { prescriptions }\end{array}$ & Resident years & $\begin{array}{l}\text { Antibiotic prescriptions } \\
\text { per resident year }\end{array}$ & $\begin{array}{l}\text { Incidence rate ratio } \\
(95 \% \mathrm{Cl})\end{array}$ \\
\hline \multicolumn{5}{|l|}{ Resident-level } \\
\hline \multicolumn{5}{|l|}{ Gender } \\
\hline Male & 9200 & 3518 & 2.61 & Ref. \\
\hline Female & 19,489 & 7213 & 2.70 & $1.00(0.95-1.06)$ \\
\hline \multicolumn{5}{|l|}{ Age } \\
\hline $65-74$ & 3823 & 1507 & 2.54 & Ref. \\
\hline $75-84$ & 10,159 & 3955 & 2.57 & $1.02(0.94-1.10)$ \\
\hline $85-94$ & 12,649 & 4556 & 2.78 & $1.08(1.00-1.17)$ \\
\hline $95+$ & 2058 & 713 & 2.89 & $1.16(1.03-1.30)$ \\
\hline \multicolumn{5}{|l|}{ Type of care } \\
\hline Residential & 8539 & 3434 & 2.49 & Ref. \\
\hline Nursing & 20,071 & 7265 & 2.76 & $1.26(1.17-1.35)$ \\
\hline \multicolumn{5}{|l|}{ Dementia } \\
\hline No & 17,325 & 5996 & 2.89 & Ref. \\
\hline Yes & 11,285 & 4703 & 2.40 & $0.86(0.81-0.92)$ \\
\hline \multicolumn{5}{|l|}{ Respite care } \\
\hline No & 27,461 & 10,184 & 2.70 & Ref. \\
\hline Yes & 1228 & 547 & 2.24 & $0.89(0.80-0.98)$ \\
\hline \multicolumn{5}{|c|}{ Entered care home during study period } \\
\hline No & 17,190 & 6742 & 2.55 & Ref. \\
\hline Yes & 11,499 & 3989 & 2.88 & $1.11(1.06-1.17)$ \\
\hline \multicolumn{5}{|l|}{ Status at end of study period } \\
\hline In home & 10,573 & 4599 & 2.30 & Ref. \\
\hline Permanently Discharged & 2340 & 906 & 2.58 & $1.14(1.05-1.24)$ \\
\hline Died & 15,776 & 5226 & 3.02 & $1.47(1.39-1.55)$ \\
\hline \multicolumn{5}{|c|}{ Number of reported infection episodes during study } \\
\hline 0 & 10,463 & 5405 & 1.94 & Ref. \\
\hline 1 & 5654 & 2206 & 2.56 & $1.52(1.42-1.62)$ \\
\hline More than 1 & 12,572 & 3121 & 4.03 & $2.22(2.07-2.37)$ \\
\hline \multicolumn{5}{|c|}{ Number of BNF chapters with repeated prescriptions (excluding antibiotics) } \\
\hline $0-1$ & 852 & 1032 & 0.83 & Ref. \\
\hline $2-4$ & 7971 & 3603 & 2.21 & $1.96(1.77-2.16)$ \\
\hline $5-7$ & 16,390 & 5267 & 3.11 & $2.48(2.25-2.73)$ \\
\hline 8 or more & 3476 & 829 & 4.19 & $3.19(2.81-3.62)$ \\
\hline \multicolumn{5}{|l|}{ Care home-level } \\
\hline \multicolumn{5}{|l|}{ Country } \\
\hline England & 19,206 & 7441 & 2.58 & Ref. \\
\hline Northern Ireland & 3971 & 1313 & 3.02 & $1.20(0.94-1.52)$ \\
\hline Scotland & 4526 & 1726 & 2.62 & $1.04(0.82-1.31)$ \\
\hline Wales & 986 & 251 & 3.93 & $1.72(0.99-3.00)$ \\
\hline \multicolumn{5}{|l|}{ Number of beds } \\
\hline$<40$ & 5708 & 1814 & 3.15 & Ref. \\
\hline $40-49$ & 6930 & 2723 & 2.54 & $0.84(0.67-1.06)$ \\
\hline
\end{tabular}


Table 2 Rates and single variable analysis of antibiotic prescribing by resident and care home characteristics (Continued)

\begin{tabular}{|c|c|c|c|c|}
\hline Variable & $\begin{array}{l}\text { Number of antibiotic } \\
\text { prescriptions }\end{array}$ & Resident years & $\begin{array}{l}\text { Antibiotic prescriptions } \\
\text { per resident year }\end{array}$ & $\begin{array}{l}\text { Incidence rate ratio } \\
(95 \% \mathrm{Cl})\end{array}$ \\
\hline $50-59$ & 7378 & 2894 & 2.55 & $0.82(0.65-1.04)$ \\
\hline $60+$ & 8673 & 3300 & 2.63 & $0.87(0.68-1.11)$ \\
\hline \multicolumn{5}{|c|}{ Median overall length of stay } \\
\hline$<1$ year & 7041 & 2653 & 2.65 & Ref. \\
\hline $1-2$ years & 18,604 & 6952 & 2.68 & $1.02(0.84-1.25)$ \\
\hline$>2$ years & 3044 & 1126 & 2.70 & $1.04(0.77-1.41)$ \\
\hline \multicolumn{5}{|c|}{ Clinical staff per 100 residents } \\
\hline$<10$ & 6941 & 2643 & 2.63 & Ref. \\
\hline $10-19$ & 15,143 & 5612 & 2.70 & $0.99(0.81-1.22)$ \\
\hline $20+$ & 6605 & 2476 & 2.67 & $1.00(0.79-1.26)$ \\
\hline \multicolumn{5}{|c|}{ Care staff per 100 residents } \\
\hline$<60$ & 7219 & 2554 & 2.83 & Ref. \\
\hline $60-79$ & 16,211 & 6187 & 2.62 & $0.89(0.73-1.09)$ \\
\hline $80+$ & 5259 & 1990 & 2.64 & $0.86(0.67-1.11)$ \\
\hline \multicolumn{5}{|c|}{ Percentage residents with dementia } \\
\hline$<10$ & 6987 & 2320 & 3.01 & Ref. \\
\hline $10-80$ & 18,411 & 7065 & 2.61 & $0.85(0.70-1.03)$ \\
\hline $80-100$ & 3291 & 1346 & 2.44 & $0.82(0.62-1.07)$ \\
\hline \multicolumn{5}{|c|}{ Percentage residents with nursing care } \\
\hline$<10$ & 3594 & 1351 & 2.66 & Ref. \\
\hline $10-80$ & 13,278 & 5055 & 2.63 & $0.89(0.69-1.14)$ \\
\hline $80-100$ & 11,817 & 4325 & 2.73 & $1.03(0.80-1.33)$ \\
\hline \multicolumn{5}{|c|}{ Number of infection incidents per bed per year } \\
\hline Less than 1 & 16,329 & 6548 & 2.49 & Ref. \\
\hline 1 to 2 & 8316 & 2887 & 2.88 & $1.14(0.94-1.37)$ \\
\hline 2 or more & 4044 & 1297 & 3.12 & $1.24(0.97-1.59)$ \\
\hline
\end{tabular}

BNF British National Formulary, Cl confidence interval, Ref. reference group

moving into a home is often linked to adverse health events, this association is also likely to represent residents in more ill health. We found variation in antibiotic prescribing rates between care homes, but this was not explained by the care home-level factors that we were able to investigate using routinely-collected data. This variation indicates scope for improvement in prescribing, and further investigation is warranted to explore the importance of other individual and contextual factors that we were not able to measure. Previous studies in care homes have identified a range of factors that may influence prescribing behaviour including past tendency of the physician to prescribe antibiotics [34, 35], presence of an antimicrobial stewardship committee [36], and practices around the use of urinary catheters [36].

We also found that a high proportion of the antibiotics used (30\%) were likely to be repeat prescriptions. The antibiotics that were most frequently repeated for long durations were azithromycin, cephalexin, nitrofurantoin and trimethoprim. These antibiotics are recommended for use as prophylaxis for chronic obstructive pulmonary disease and urinary tract infections [37, 38]. Long-term prophylactic use of antibiotics may therefore represent an important opportunity for improving antibiotic stewardship in care homes, particularly given that there is limited evidence that using antibiotics as prophylaxis is beneficial in this setting [39].

Our findings have implications for antimicrobial stewardship intervention design and implementation. Reviews of existing interventions in care homes have found few high quality studies [40-43], and the behaviours targeted by interventions are often poorly specified. We have identified two possible targets for future behavioural interventions: reducing long term prophylactic prescriptions and optimising antibiotic use for residents who have recently moved into a home or are near the end of life. Our findings also highlight the need to investigate other behaviours related to stewardship that 
Table 3 Multivariable analysis of antibiotic prescribing

\begin{tabular}{|c|c|}
\hline Variable & Adjusted incidence rate ratio $(95 \% \mathrm{Cl})$ \\
\hline \multicolumn{2}{|l|}{ Gender } \\
\hline Male & Ref. \\
\hline Female & $1.03(0.98-1.08)$ \\
\hline \multicolumn{2}{|l|}{ Age } \\
\hline $65-74$ & Ref. \\
\hline $75-84$ & $0.96(0.89-1.04)$ \\
\hline $85-94$ & $0.99(0.92-1.07)$ \\
\hline $95+$ & $1.11(0.99-1.24)$ \\
\hline \multicolumn{2}{|l|}{ Type of care } \\
\hline Residential & Ref. \\
\hline Nursing & $1.21(1.13-1.30)$ \\
\hline \multicolumn{2}{|l|}{ Dementia } \\
\hline No & Ref. \\
\hline Yes & $0.94(0.89-1.00)$ \\
\hline \multicolumn{2}{|l|}{ Respite care } \\
\hline No & Ref. \\
\hline Yes & $1.12(1.0-1.24)$ \\
\hline \multicolumn{2}{|c|}{ Entered care home during study period } \\
\hline No & Ref. \\
\hline Yes & $1.37(1.30-1.44)$ \\
\hline \multicolumn{2}{|l|}{ Status at end of study period } \\
\hline In home & Ref. \\
\hline Permanently Discharged & $1.44(1.32-1.57)$ \\
\hline Died & $1.58(1.50-1.67)$ \\
\hline \multicolumn{2}{|c|}{ Number of reported infection episodes during study } \\
\hline 0 & Ref. \\
\hline 1 & $1.44(1.35-1.54)$ \\
\hline More than 1 & $2.09(1.96-2.24)$ \\
\hline \multicolumn{2}{|c|}{$\begin{array}{l}\text { Number of BNF chapters with repeated prescriptions (excluding } \\
\text { antibiotics) }\end{array}$} \\
\hline $0-1$ & Ref. \\
\hline $2-4$ & $1.94(1.76-2.14)$ \\
\hline $5-7$ & $2.38(2.16-2.62)$ \\
\hline 8 or more & $2.89(2.54-3.28)$ \\
\hline
\end{tabular}

BNF British National Formulary, $\mathrm{Cl}$ confidence interval; Ref. reference group

precede an antibiotic being prescribed such as identifying, diagnosing, escalating, and managing suspected infections. Safely reducing antibiotic use in care homes could be achieved by improved infection prevention and control measures such as vaccination, isolation of symptomatic residents, handwashing, exclusion of symptomatic visitors, improved catheter management, regular movement, and good skin care [44].

A strength of this study was its large scale and use of novel linkages between care home administrative data and pharmacy drug dispensing data. This allowed us to explore relationships between antibiotic prescribing rates and resident and care home characteristics at scale for the first time in the UK. As the majority of other estimates of antibiotic use in care homes in the UK have been based on point prevalence data or small data sets, our results are more representative of the population and less likely to be affected by seasonal variation.

A limitation of this study was that, although the pharmacy chain is contracted to provide all prescriptions to the care home chain, the data suggest that this does not always happen in practice. To account for this, we conducted two analyses with different inclusion criteria. The main analysis included all residents from care homes from which at least $75 \%$ of residents matched to pharmacy data, and the sensitivity analysis included all residents (from any care home) that matched to at least one pharmacy record. As expected, the sensitivity analysis produced a slightly higher rate (2.81 antibiotic prescriptions per resident year compared to 2.61 in the main analysis), as this analysis excluded any residents who did not have any prescriptions. However, both analyses may still be underestimates of prescribing if many antibiotics were dispensed from different pharmacies. Characteristics of residents and care homes included and excluded from the main analysis (additional file 2) were similar, suggesting that factors associated with increased prescribing are not due to bias in the data. Antibiotics dispensed during hospital stays were also not captured in this study.

Another limitation was that our analysis used data from administrative care home systems that were not designed for research. Information on temporary absences from homes, for example during hospital stays, or temporary stays in homes funded by the local authority were not available. Although we found increased antibiotic prescribing for residents with more probable comorbidities, this was based on a crude measure of repeat prescriptions of non-antibiotic drugs. We did not have information on specific co-morbidities or other medical risk factors such as catheter use. Since the pharmacy data does not include indication for the drug dispensed, we were also not able to directly assess the appropriateness of the antibiotic prescriptions. However, we performed exploratory analyses examining how well the antibiotic prescriptions matched the broad category of infection reported in the care home incident monitoring systems. This showed that, in general, antibiotics were of expected classes for a given infection category. Further work is needed to investigate prescribing patterns for specific types of infection with or without microbiological confirmation. Improved recording of care home residency in primary and secondary care records, and enhanced data collection within care homes, would enable these factors to be assessed in greater detail. 


\section{Conclusions}

In summary, this large-scale study has demonstrated high rates of antibiotic use for residents of care homes in the UK and a high degree of variation across homes. Although antibiotics were mainly used for the most unwell residents, the high variation in antibiotic use suggests scope for improved stewardship. Our analysis has identified potential targets for future stewardship interventions, but further work is needed to characterise the drivers of prescribing in care homes to inform the development of interventions that target the influences of prescribing.

\section{Supplementary information}

Supplementary information accompanies this paper at https://doi.org/10. 1186/s12913-020-05422-z.

Additional file 1: Distribution of time between prescriptions of the same antibiotic for the same resident.

Additional file 2. Characteristics of residents and care homes included and excluded from main analysis

Additional file 3: Country-specific analyses of rates of antibiotic prescribing in care homes Table 1. Care home Table 2. Rates and single variable negative binomial regressioncharacteristics Table 3. Multivariable negative binomial regression

Additional file 4: Sensitivity analysis Table 1. Resident and care home characteristics Table $\mathbf{2}$. Rates and single variable analysis of antibiotic prescribing by resident and care home characteristics Table $\mathbf{3}$ Multivariable analysis of antibiotic prescribing

\section{Abbreviations}

alRR: Adjusted Incidence Rate Ratio; ATC: Anatomical Therapeutic Chemical; BNF: British National Formulary; Cl: Confidence interval; CQC: Care Quality Commission; ECDC: European Centre for Disease Prevention and Control; HALT: Healthcare-associated infections in long-term care facilities; IQR: Interquartile range

\section{Acknowledgements}

The PASS research group comprises: Anderson N, Atkins L, Conolly A, Crayton E, Denaxas S, Dutey-Magni P, Elsay N, Forbes G, Fragaszy EB, Freemantle N, Fuller C, Gill M, Hayward AH, Horne R, Jhass A, Kostkova P, Lorencatto F, Michie S, Mindell J, Richardson M, Robson J, Rockenschaub P, Royston C, Shallcross LJ, Smith CM, Sutton E, Thomas J, Tarrant C, Traina R, Richardson E, West J, Williams $H$.

We would like to thank Andy Normington for providing pharmacy data and Stephen Simon for providing care home administrative data.

\section{Authors' contributions}

CMS led the analysis and drafted the manuscript. ACH, LJS, and the PASS study investigators developed the concept for the study. HW provided data. ACH, LJS, HW, AJ, and SP contributed to the analysis. EC, FL and SM contributed to interpretation. All authors critically reviewed the manuscript, contributed to its revision, and approved the final version submitted.

\section{Funding}

This work was supported by the Economic and Social Research Council, grant number ES/P008321/1, as part of the Preserving Antibiotics through Safe Stewardship (PASS) project. Professor Hayward is a National Institute for Health Research (NIHR) Senior Investigator. The views expressed in this publication are those of the authors and not necessarily those of the NHS, the National Institute for Health Research or the Department of Health and Social Care. The funders played no role in the design of the study, collection, analysis or interpretation of data.

\section{Availability of data and materials}

The datasets analysed during the current study are not publicly available as they were used through agreement with the care home provider (Four Seasons Health Care) and pharmacy (Boots UK). Data are however available from the authors upon reasonable request and with permission of Four Seasons Health Care and Boots UK.

\section{Ethics approval and consent to participate}

This study was approved by the UCL Research Ethics Committee (ID 11813/ 002), which waived the need for individual informed consent because the study was based on routinely-collected pseudonomised data. Administrative permissions for accessing data were granted through Data Sharing Agreements between UCL and Boots UK/Four Seasons Health Care.

\section{Consent for publication}

Not applicable.

\section{Competing interests}

The authors declare that they have no competing interests.

\section{Author details}

${ }^{1}$ Institute of Health Informatics, University College London, London NW1 2DA, UK. ${ }^{2}$ Four Seasons Health Care, Norcliffe House, Station Road, Wilmslow, Cheshire SK9 1BU, UK. ${ }^{3}$ Research Department of Primary Care and Population Health, University College London, London NW3 2PF, UK. ${ }^{4}$ Centre for Behaviour Change, University College London, WC1E 7HB, London, UK. ${ }^{5}$ Institute of Epidemiology and Health Care, University College London, WC1E 7HB, London, UK.

Received: 20 January 2020 Accepted: 10 June 2020

Published online: 18 June 2020

\section{References}

1. Care Quality Commission. The state of health care and adult social care in England 2017/18 [Internet]. 2017. Available from: www.cqc.org.uk/ stateofcare [cited 2019 Jul 30].

2. The Regulation and Quality Improvement Authority NI. Annual Quality Report 2017-18 [Internet]. Available from: https://www.rqia.org.uk/RQIA/files/ d9/d9ede6b4-90d5-4465-b7be-5ba4ad4f39ba.pdf. [cited 2019 Jul 30].

3. HS National Services Scotland ISD. Care Home Census for Adults in Scotland [Internet]. 2007. Available from: https://www.statisticsauthority.gov.uk/ national-statistician/types-of-official-statistics/ [cited 2019 Jul 30].

4. StatsWales. CIW Services and Places by Setting Type and Year [Internet]. Available from: https://statswales.gov.wales/Catalogue/Health-and-SocialCare/Services-for-Social-Care-and-Childrens-Day-Care/ cssiwservicesandplaces-by-setting-year. [cited 2019 Jul 30].

5. National Health Service. The NHS Long Term Plan [Internet]. 2019. Available from: www.longtermplan.nhs.uk [cited 2019 Feb 7].

6. NHS. Care homes [Internet]. 2019. Available from: https://www.nhs.uk/ conditions/social-care-and-support-guide/care-services-equipment-and-carehomes/care-homes/ [cited 2019 Oct 22].

7. van Buul LW, van der Steen JT, Veenhuizen RB, Achterberg WP, Schellevis FG, Essink RTGM, et al. Antibiotic use and resistance in long term care facilities. J Am Med Dir Assoc. 2012;13(6):568.e1-568.13. Available from: http://ovidsp.ovid.com/ovidweb.cgi? T=JS\&PAGE=reference\&D= med8\&NEWS=N\&AN=22575772.

8. Inns T, Clough HE, Harris JP, Vivancos R, Adams N, O'Brien SJ. Estimating the burden of care home gastroenteritis outbreaks in England, 2014-2016. BMC Infect Dis. 2019;19(1):12. Available from: [cited 2019 Feb 11] https:// bmcinfectdis.biomedcentral.com/articles/https://doi.org/10.1186/s12879-0183642-3.

9. Nicolle LE, Bentley DW, Garibaldi R, Neuhaus EG, Smith PW. Antimicrobial Use in Long-Term-Care Facilities. Infect Control Hosp Epidemiol. 2015/01/ 02. 2000;21(8):537-545. Available from: https://www.cambridge.org/core/ article/antimicrobial-use-in-longtermcare-facilities/A6648B5AC6747E0516 $035687324 F 7$ C63.

10. Sundvall P-D, Stuart B, Davis M, Roderick P, Moore M. Antibiotic use in the care home setting: a retrospective cohort study analysing routine data. BMC Geriatr. 2015:15:71. Available from: http://ovidsp.ovid.com/ovidweb.cgi? T= JS\&PAGE $=$ reference\&D=medc\&NEWS=N\&AN=26108340. 
11. Smith P, Sherlaw-Johnson C, Ariti C, Bardsley M. Focus on: Hospital admissions from care homes. 2015. Available from: www.qualitywatch.org.uk [cited 2019 Feb 11].

12. European Centre for Disease Prevention and Control. Point prevalence survey of healthcare-associated infections and antimicrobial use in European long-term care facilities. May-September 2010. Stockholm: European Centre for Disease Prevention and Control; 2014. Available from: www.ecdc.europa.eu [cited 2019 Jul 25].

13. European Centre for Disease Prevention and Control. Point prevalence survey of healthcare-associated infections and antimicrobial use in European long-term care facilities. April-May 2013. Stockholm: European Centre for Disease Prevention and Control; 2014. Available from: www.ecdc. europa.eu [cited 2019 Jul 25].

14. Ricchizzi E, Latour K, Karki T, Buttazzi R, Jans B, Moro ML, et al. Antimicrobial use in European long-term care facilities: results from the third point prevalence survey of healthcare-associated infections and antimicrobial use, 2016 to 2017. Lusignani LS, Latour K, Jans B, Hedlova D, Jindrak V, Bosnjak Z, Budimir A, Gabriel E, Jensen CS, Lyytikainen O, Sarvikivi E, Savey A, Daniau C, Schmidt N, Ruscher C, Adami ME, Panagiotakis SH, Veress I, Burns K, Murphy H, Zotti CM, Furmenti MF, Avelyte J SR, editor. Euro Surveill. 2018;23(46). Available from: http:// ovidsp.ovid.com/ovidweb.cgi? T=JS\&PAGE=reference\&D=prem\&NEWS= $\mathrm{N} \& A N=30458913$.

15. Thornley T, Ashiru-Oredope D, Beech E, Howard P, Kirkdale CL, Elliott H, et al. Antimicrobial use in UK long-term care facilities: results of a point prevalence survey. J Antimicrob Chemother. 2019;74(7):2083-2090. Available from: http://ovidsp.ovid.com/ovidweb.cgi? T=JS\&PAGE=reference\&D= prem\&NEWS $=\mathrm{N} \& A N=30993326$.

16. Thornley T, Ashiru-Oredope D, Normington A, Beech E, Howard P. Antibiotic prescribing for residents in long-term-care facilities across the UK. J Antimicrob Chemother. 2019;74(5):1447-51. Available from: http://ovidsp. ovid.com/ovidweb.cgi?T=JS\&PAGE=reference\&D=medp\&NEWS=N\&AN=306 98718.

17. Shallcross L, Beckley N, Rait G, Hayward A, Petersen I. Antibiotic prescribing frequency amongst patients in primary care: a cohort study using electronic health records. J Antimicrob Chemother. 2017;72(6):1818-1824. Available from: [cited 2019 Jul 23] https://academic.oup.com/jac/article-lookup/doi/ https://doi.org/10.1093/jac/dkx048.

18. Dolk FCK, Pouwels KB, Smith DRM, Robotham J V, Smieszek T. Antibiotics in primary care in England: which antibiotics are prescribed and for which conditions? J Antimicrob Chemother. 201873(suppl_2):ii2-i10. Available from: https://academic.oup.com/jac/article/73/suppl_2/ii2/4841822 [cited 2019 Jul 23];:

19. Office for National Statistics. Rural Urban Classification (2011) of Lower Layer Super Output Areas in England and Wales - data.gov.uk [Internet]. [cited 2019 Jul 30]. Available from: https://data.gov.uk/dataset/b1165cea-2655-4 cf7-bf22-dfbd3cdeb242/rural-urban-classification-2011-of-lower-layer-superoutput-areas-in-england-and-wales.

20. Scottish Government. Urban Rural Classification. Available from: https:// www2.gov.scot/Topics/Statistics/About/Methodology/ UrbanRuralClassification. [cited 2019 Jul 30].

21. Northern Ireland Statistics and Research Agency. Settlement 2015 Documentation. Available from: https://www.nisra.gov.uk/publications/ settlement-2015-documentation. [cited 2019 Jul 30].

22. Department of Communities and Local Government. The English Indices of Deprivation 2015. London: Department of Communities and Local Government; 2015.

23. Welsh Government. Welsh Index of Multiple Deprivation. Available from: https://gweddill.gov.wales/statistics-and-research/welsh-index-multipledeprivation/?lang=en. [cited 2019 Jul 30].

24. Scottish Government. Scottish Index of Multiple Deprivation. Available from: https://www2.gov.scot/Topics/Statistics/SIMD. [cited 2019 Jul 30].

25. Northern Ireland Statistics and Research Agency. Northern Ireland Multiple Deprivation Measure 2017 (NIMDM2017) [Internet]. Available from: https:// www.nisra.gov.uk/statistics/deprivation/northern-ireland-multipledeprivation-measure-2017-nimdm2017. [cited 2019 Jul 30].

26. Medicines Complete. British National Formulary [Internet]. Available from: https://www.medicinescomplete.com/\#/browse/bnf/therapeuticAreas. [cited 2019 Jul 30]

27. OpenPrescribing. All BNF sections [Internet]. Available from: https:// openprescribing.net/bnf/. [cited 2019 Dec 16].
28. WHO Collaborating Centre for Drug Statistics Methodology. ATC/DDD Index [Internet]. Available from: https://www.whocc.no/atc ddd index/. [cited 2019 Oct 3].

29. Bates D, Mächler M, Bolker B, Walker S. Fitting Linear Mixed-Effects Models Using Ime4. J Stat Softw; Vol 1, Issue 1 [Internet]. 2015; Available from: https://www.jstatsoft.org/v067/i01.

30. Gillespie D, Hood K, Bayer A, Carter B, Duncan D, Espinasse A, et al. Antibiotic prescribing and associated diarrhoea: a prospective cohort study of care home residents. Age Ageing. 2015;44(5):853-860. Available from: http://ovidsp.ovid.com/ovidweb.cgi? T=JS\&PAGE=reference\&D= med11\&NEWS $=$ N\&AN=26104506.

31. Benoit SR, Nsa W, Richards CL, Bratzler DW, Shefer AM, Steele LM, et al. Factors associated with antimicrobial use in nursing homes: a multilevel model. J Am Geriatr Soc. 2008;56(11):2039-2044. Available from: http:// ovidsp.ovid.com/ovidweb.cgi? T=JS\&PAGE=reference\&D=med6\&NEWS= $\mathrm{N} \& A N=19016937$.

32. Marra F, McCabe M, Sharma $P$, Zhao B, Mill C, Leung $V$, et al. Utilization of Antibiotics in Long-Term Care Facilities in British Columbia, Canada. J Am Med Dir Assoc. 2017;18(12):1098.e1-1098.e11. Available from: http://ovidsp ovid.com/ovidweb.cgi? T=JS\&PAGE=reference\&D=med13\&NEWS=N\&AN= 29169741.

33. Daneman N, Bronskill SE, Gruneir A, Newman AM, Fischer HD, Rochon PA, et al. Variability in Antibiotic Use Across Nursing Homes and the Risk of Antibiotic-Related Adverse Outcomes for Individual Residents. JAMA Intern Med. 2015;175(8):1331-1339. Available from: http://ovidsp.ovid.com/ ovidweb.cgi? T=JS\&PAGE=reference\&D=med11\&NEWS=N\&AN=26121537.

34. Daneman N, Gruneir A, Bronskill SE, Newman A, Fischer HD, Rochon PA, et al. Prolonged antibiotic treatment in long-term care: role of the prescriber. JAMA Intern Med. 2013;173(8):673-682. Available from: http:// ovidsp.ovid.com/ovidweb.cgi? T=JS\&PAGE=reference\&D=med9\&NEWS= $N \& A N=23552741$.

35. Daneman N, Campitelli MA, Giannakeas V, Morris AM, Bell CM, Maxwell CJ, et al. Influences on the start, selection and duration of treatment with antibiotics in long-term care facilities. CMAJ. 2017;189(25):E851-E860. Available from: http://ovidsp.ovid.com/ovidweb.cgi? T=JS\&PAGE= reference\&D=med $13 \&$ NEWS $=\mathrm{N} \& A N=28652480$.

36. Tandan M, Burns K, Murphy H, Hennessy S, Cormican M, Vellinga A. Antimicrobial prescribing and infections in long-term care facilities (LTCF): a multilevel analysis of the HALT 2016 study, Ireland, 2017. Euro Surveill. 2018; 23(46). Available from: http://ovidsp.ovid.com/ovidweb.cgi? T=JS\&PAGE= reference $\& D=$ prem $2 \& N E W S=N \& A N=30458910$.

37. Global Initiative for Chronic Obstructive Lung Disease. Global Initiative for Chronic Obstructive Lung Disease Global Initiative for Chronic Obstructive Lung Disease POCKET GUIDE TO COPD DIAGNOSIS, MANAGEMENT, AND PREVENTION A Guide for Health Care Professionals [Internet]. 2019. Available from: www.goldcopd.org [cited 2019 Dec 11].

38. NICE. Recommendations | Urinary tract infection (recurrent): antimicrobial prescribing | Guidance [Internet]. 2018. Available from: https://www.nice.org. uk/guidance/ng112/chapter/Recommendations\#choice-of-antibioticprophylaxis [cited 2019 Dec 11].

39. Ahmed H, Davies F, Francis N, Farewell D, Butler C, Paranjothy S. Long-term antibiotics for prevention of recurrent urinary tract infection in older adults: systematic review and meta-analysis of randomised trials. BMJ Open 2017;7: e015233.

40. Fleming A, Browne J, Byrne S. The effect of interventions to reduce potentially inappropriate antibiotic prescribing in long-term care facilities: a systematic review of randomised controlled trials. Drugs Aging. 2013;30(6): 401-408. Available from: http://ovidsp.ovid.com/ovidweb.cgi? T=JS\&PAGE= reference $\& D=$ med9\&NEWS $=\mathrm{N} \& A N=23444263$.

41. Feldstein D, Sloane PD, Feltner C. Antibiotic Stewardship Programs in Nursing Homes: A Systematic Review. J Am Med Dir Assoc. 2018;19(2):110116. Available from: https://www.sciencedirect.com/science/article/pii/S1525 861017303626?via\%3Dihub [cited 2019 Jul 25]

42. Falcone M, Paul M, Yahav D, Orlando G, Tiseo G, Prendki V, et al. Antimicrobial consumption and impact of antimicrobial stewardship programmes in long-term care facilities. Clin Microbiol Infect. 2019;25(5): 562-569. Available from: http://ovidsp.ovid.com/ovidweb.cgi? T=JS\&PAGE= reference $\& D=$ prem \&NEWS=N\&AN=30076978.

43. Lorencatto F, Charani E, Sevdalis N, Tarrant C, Davey P. Driving sustainable change in antimicrobial prescribing practice: how can social and behavioural sciences help? J Antimicrob Chemother. 2018;73(10):2613-2624. 
Available from: http://www.ncbi.nlm.nih.gov/pubmed/30020464. [cited 2019 Oct 23].

44. Eilidh M Duncan, Esmita Charani, Janet E Clarkson, Jill J Francis, Katie Gillies, Jeremy M Grimshaw, Winfried V Kern, Fabiana Lorencatto, Charis A Marwick, Jo McEwen, Ralph Möhler, Andrew M Morris, Craig R Ramsay, Susan Rogers Van Katwyk, Magdalena Rzewuska, Brita Skodvin, Ingrid Smith, Kathryn N Suh, Peter G Davey]. 2020;75(5):1338-46. https://doi.org/10.1093/jac/ dkaa001.

\section{Publisher's Note}

Springer Nature remains neutral with regard to jurisdictional claims in published maps and institutional affiliations.

Ready to submit your research? Choose BMC and benefit from:

- fast, convenient online submission

- thorough peer review by experienced researchers in your field

- rapid publication on acceptance

- support for research data, including large and complex data types

- gold Open Access which fosters wider collaboration and increased citations

- maximum visibility for your research: over $100 \mathrm{M}$ website views per year

At $\mathrm{BMC}$, research is always in progress.

Learn more biomedcentral.com/submissions 